\title{
Effect of L-carnitine supplementation on drake semen quality
}

\author{
H.J. Al-Daraji ${ }^{\#} \&$ A.O. Tahir \\ University of Baghdad, College of Agriculture, Department of Animal Production, Baghdad, Iraq
}

(Received 22 May 2013; Accepted 13 November 2013; First published online 30 January 2014)

\begin{abstract}
Copyright resides with the authors in terms of the Creative Commons Attribution 2.5 South African Licence
See: http://creativecommons.org/licenses/by/2.5/za

Condition of use: The user may copy, distribute, transmit and adapt the work, but must recognise the authors and the South African Journal of Animal Science.
\end{abstract}

\begin{abstract}
This study was conducted to determine the effect on semen quality traits of supplementing the diets of Iraqi drakes with L-carnitine. Forty eight male Iraqi ducks, 30 weeks old, were randomly allocated to four treatments with 12 drakes per treatment group, replicated three times, with four drakes per replicate. The treatment groups consisted of birds fed a diet free of L-carnitine $\left(T_{1}\right.$, control group); birds fed a diet containing $50 \mathrm{mg} \mathrm{L}$-carnitine/kg diet $\left(\mathrm{T}_{2}\right)$; birds fed a diet containing $100 \mathrm{mg} \mathrm{L}$-carnitine/kg diet $\left(\mathrm{T}_{3}\right)$; and birds fed a diet containing $150 \mathrm{mg} \mathrm{L-carnitine/kg} \mathrm{diet.} \mathrm{The} \mathrm{drakes} \mathrm{were} \mathrm{fed} \mathrm{the} \mathrm{experimental} \mathrm{diets} \mathrm{only} \mathrm{during} \mathrm{the}$ experimental period, which lasted three months. The semen quality traits that were investigated were ejaculate volume, mass and individual motility of spermatozoa, spermatocrit, spermatozoa concentration, percentages of dead and abnormal spermatozoa and acrosomal abnormalities. Supplementing the diet of drakes with L-carnitine at the levels of $50-150 \mathrm{mg} / \mathrm{kg}$ diet significantly increased ejaculate volume, spermatocrit, mass and individual motility of spermatozoa, and concentration of spermatozoa, while percentages of dead and abnormal spermatozoa and acrosomal abnormalities were decreased. However, $T_{4}$ (150 mg L-carnitine/kg diet) recorded the best results in relation to all semen quality traits included in this study. Dietary supplementation with L-carnitine improved the semen quality of local drakes; therefore L-carnitine can be used as an efficient feed additive to improve the reproductive performance of male ducks.
\end{abstract}

Keywords: Carnitine, ducks, reproductive performance

\#Corresponding author: hazimaldaraji@coagri.uobaghdad.edu.iq

\section{Introduction}

L-Carnitine ( $\beta$-hydroxy- $\gamma$-trimethylammonium butyrate) is a highly polar natural compound found in microorganisms, plants and animals (Arslan et al., 2003). It has been shown to have beneficial effects on the heart and skeletal muscles, and conditions such as disorders of the central nervous system, certain types of male sterility and some disorders in newborns (Benvenga et. al., 2004). Mammals and birds are able to synthesize carnitine from the amino acids, L-methionine and L-lysine, but approximately two thirds of the daily requirements of human beings come from an omnivorous diet (Griffin et al., 1990). Carnitine is probably found in all animal species, in numerous organisms and in plants (Kleber, 1997; Elgazzar et al., 2012). It has been established that an adequate supply of L-carnitine is necessary for the maintenance of good health. L-carnitine transports long-chain fatty acids across the mitochondrial membrane to be metabolized, and aids in the release of stored body fat, and triglycerides into the bloodstream for energy. Triglycerides are the major substrate for the production of energy in the heart and skeletal muscles. Access to L-carnitine is believed to increase energy levels for long-term aerobic activity. L-carnitine is responsible for muscle contraction, regulation of protein balance and maintenance of a healthy heart. Research suggests that an adequate supply of L-carnitine could be instrumental in the treatment of diabetes, chronic fatigue syndrome, kidney and liver disease (Karadeniz et al., 2008). It reduces fat deposition by reducing the availability of lipids for peroxidation (Neuman et al., 2002). It transports fatty acids into the mitochondria for $\beta$-oxidation to generate adenosine triphosphate (ATP) energy (Neuman et al., 2002).

The effects of carnitine supplementation have been studied in trained pigeons, turkeys, broilers and layers. Leibetseder (1995) determined the effects of supplementary dietary L-carnitine on carcass composition, performance of chickens, and hatchability. He found that performance and abdominal fat were not influenced by carnitine, and that hatchability of the birds fed with carnitine was higher, and the carnitine levels of these eggs were higher than in the control group. Al-Hayani (2012) showed that including 300 $\mathrm{mg} / \mathrm{kg} \mathrm{L}$-carnitine in the diets of guinea fowl improved productive traits such as egg production rate, cumulative egg number, egg weight, feed conversion ratio and egg mass. It also improved egg quality traits 
such as yolk weight, yolk diameter, yolk height, albumen height and Haugh unit, compared with the control group. Supplementation of L-carnitine may improve energy production from fatty acids to facilitate the hatching process in chicken embryos (Zhai et al., 2008a). Dietary supplementation of L-carnitine increased sperm concentration, count and motility, semen volume and decreased lipid peroxidation of spermatozoa in breeding roosters (Neuman et al., 2002; Golzar Adabi et al., 2006; Zhai et al., 2007). L-carnitine plays a critical role in the maturation and motility of spermatozoa within the male reproductive tract ( $\mathrm{Ng}$ et al., 2004).

There is a paucity of information on the effect of dietary L-carnitine on the reproductive performance of the male duck. Therefore, the aim of this study was to investigate the effects of dietary supplementation with different levels of L-carnitine on the semen quality of drakes.

\section{Materials and Methods}

The experiment was conducted on 48 male Iraqi ducks that were 30 weeks old and weighed $1.75-2.0$ $\mathrm{kg}$. The males were kept in individual cages (0.6/0.8/0.6 $\mathrm{m}$ in size) and fed ad libitum, except that the drakes were restricted from feed $12 \mathrm{~h}$ prior to semen collection. The drakes were separated into four groups, with one control group and three treatment groups. Each treatment was replicated three times, with four birds per replicate. The experiment was divided into two stages. During the first stage, which was the first two weeks, the birds were allowed to adapt to the new diet and conditions. All experimental groups were fed a mash diet. The diets were formulated to be isoenergetic and isonitrogenous and their composition was determined according to the NRC (1994). The composition of the basal diet is presented in Table 1.

Table 1 Percentage of ingredients and calculated chemical analysis of the experimental basal diet

\begin{tabular}{lc}
\hline Ingredients & (g/kg) \\
\hline & 390 \\
Yellow maize & 337 \\
Wheat & 130 \\
Soybean meal (44 \%) & 50 \\
Concentration protein * & 60 \\
Limestone & 20 \\
Vegetable oil & 10 \\
Dicalcium phosphate & 3 \\
NaCl & 1000 \\
Total & \\
\hline Calculated chemical composition** & 152 \\
\hline Crude protein (g/kg) & 12.25 \\
Energy (MJ/kg) & 7 \\
Lysine (g/kg) & 3 \\
Methionine (g/kg) & 2.5 \\
Cysteine (g/kg) & 27 \\
Calcium (g/kg) & 3 \\
Available phosphorus (g/kg) & \\
&
\end{tabular}

\footnotetext{
*Concentration protein (BROCON - 5 SPECIAL W).

** Each $1 \mathrm{~kg}$ of vitamin and mineral premix (imported from China) contains: $3.25 \%$ crude protein; $3.5 \%$ crude fat; $1 \%$ crude fibre; $6 \%$ calcium; $3 \%$ available phosphorus; $2.2 \%$ sodium; $3.5 \%$ methionine; $3.90 \%$ methionine + cysteine; $3.25 \%$ lysine; $4.59 \mathrm{MJ}$ metabolisable energy/kg; $200000 \mathrm{IU}$ vit $\mathrm{A} ; 40000 \mathrm{IU}$ vit. $\mathrm{D}_{3} ; 500 \mathrm{mg}$ vit. E; $30 \mathrm{mg}$ vit. K3; $15 \mathrm{mg}$ vit. $\mathrm{B}_{1}$ and $\mathrm{B}_{2} ; 150 \mathrm{mg}$ vit. $\mathrm{B}_{3} ; 20 \mathrm{mg}$ vit. $\mathrm{B}_{6} ; 300 \mathrm{mg}$ vit. $\mathrm{B}_{12} ; 10 \mathrm{mg}$ folic acid; $50 \mathrm{mg}$ biotin; $800 \mathrm{mg}$ zinc; $100 \mathrm{mg}$ copper; $15 \mathrm{mg}$ iodine; $1 \mathrm{mg}$ iron; $2 \mathrm{mg}$ selenium; $1.2 \mathrm{mg}$ manganese; $6 \mathrm{mg}$ cobalt and antioxidant $90 \mathrm{mg}$.

${ }^{* *}$ Calculated chemical composition analysis adopted by NRC (1994).
}

In the second stage, four experimental diets were formulated to provide a similar nutrient profile, with the exception of four graded levels of L-carnitine $(0,50,100$ and $150 \mathrm{mg}$ per $\mathrm{kg}$ diet, respectively). Therefore, the arrangement of treatments consisted of birds fed a diet free of $L$-carnitine $\left(T_{1}\right.$, control group); birds fed a diet containing $50 \mathrm{mg} \mathrm{L-carnitine/kg}$ diet $\left(\mathrm{T}_{2}\right)$; birds fed a diet containing $100 \mathrm{mg} \mathrm{L-carnitine/kg}$ of 
diet $\left(T_{3}\right)$; and birds fed a diet containing $150 \mathrm{mg} \mathrm{L}$-carnitine/kg diet $\left(T_{4}\right)$. The drakes were fed the experimental diets ad libitum in this stage of the experiment, which lasted three months, during which semen samples were collected. These drakes were trained for semen collection 14 days before the actual collection began. Semen was collected fortnightly from all drakes involved in this experiment. The semen collection procedure was carried out with a dorsal-abdominal manual massage procedure (Al-Daraji et al., 2012). Semen traits were analysed for ejaculate volume, mass and individual motility of spermatozoa, spermatocrit, spermatozoa concentration and percentages of dead spermatozoa, abnormal spermatozoa, and acrosomal abnormalities. Spermatozoa concentration was determined using the haemocytometer method, and the technique involved mixing semen with appropriate diluents at a ratio of $1: 200$ with an eosin solution. The evaluation of sperm motility from the diluted semen was conducted at $400 \times$ magnification on a warm stage. A drop of the diluted semen was placed on a preheated slide and a cover slip was placed over the slide; the cover slip helped to prevent overflow, allowed a uniform film to form, and prevented quick drying of the semen. The remnant of the semen was measured to evaluate the percentage of live and dead spermatozoa as determined from $10 \mu \mathrm{L}$ semen, mixed with $50 \mu \mathrm{L}$ of eosin-nigrosin stain to make a thin smear. The smear was air-dried for $10 \mathrm{~min}$. At least 200 spermatozoa were examined (400x) under emulsion oil and those with differential morphology were counted. These traits were evaluated according the procedures reported by Al-Daraji (2002; 2007a; b). Data were analysed statistically using the SAS general linear model procedure (SAS, 2004). Test of significance for the differences between means of each classification was done by the Duncan's multiple range test (Duncan, 1955).

\section{Results and Discussion}

As seen in Table 2, there was an increase $(P<0.01)$ in the semen ejaculate volume of drakes supplemented with L-carnitine. The highest semen volume was observed in $T_{4}(0.41 \mathrm{~mL})$, while the lowest was in $\mathrm{T}_{1}(0.22 \mathrm{~mL})$. The effect of supplementation of L-carnitine on mass activity of spermatozoa of drakes is illustrated in Table 3. Mass activity of spermatozoa of drakes supplemented with L-carnitine was higher $(P<0.01)$ than that of the control. $\mathrm{T}_{4}$ had the highest mass activity of spermatozoa during the three-month experimental period $(78.8 \%, 79.7 \%$ and $82.3 \%$, respectively). However, no difference $(P>0.05)$ was noted in the mass activity of spermatozoa in $\mathrm{T}_{2}$ and $\mathrm{T}_{3}$ during the third month. Results in Table 4 revealed that supplementation of L-carnitine increased $(P<0.01)$ the individual motility of spermatozoa of drakes compared with the control. Drakes in $\mathrm{T}_{4}$ had the highest (86.6\%) individual motility of spermatozoa, while those in $T_{1}$ had the lowest (74.3\%). There was no significant difference between $T_{2}$ and $T_{3}$ in the individual motility of spermatozoa. Table 5 presents the effects of L-carnitine supplementation on the spermatocrit of the drakes. There was an increase $(P<0.01)$ in the average spermatocrit for all treatment groups supplemented with L-carnitine, compared with the control group. $\mathrm{T}_{4}$ recorded the highest values during the three months of the experiment.

Spermatozoa concentrations for the treatment groups are given in Table 6. Sperm concentration means ranged from $2.30 \times 10^{9}$ cell $/ \mathrm{mL}$ to $4.77 \times 10^{9} \mathrm{cell} / \mathrm{mL}$.

Table 2 Effect of dietary L-carnitine on ejaculate volume $(\mathrm{mL})$ (mean $\pm \mathrm{SE})$ of drakes

\begin{tabular}{ccccc}
\hline \multirow{2}{*}{ Treatments } & \multicolumn{3}{c}{ Periods } & $\begin{array}{c}\text { Overall } \\
\text { mean }\end{array}$ \\
\cline { 2 - 4 } & First month & Second month & Third month & \\
\hline T1 & $0.216^{\mathrm{d}} \pm 0.012$ & $0.230^{\mathrm{d}} \pm 0.005$ & $0.243^{\mathrm{d}} \pm 0.003$ & $0.22^{\mathrm{d}} \pm 0.006$ \\
$\mathrm{~T} 2$ & $0.276^{\mathrm{c}} \pm 0.006$ & $0.286^{\mathrm{c}} \pm 0.003$ & $0.310^{\mathrm{c}} \pm 0.005$ & $0.29^{\mathrm{c}} \pm 0.004$ \\
T3 & $0.323^{\mathrm{b}} \pm 0.006$ & $0.363^{\mathrm{b}} \pm 0.006$ & $0.376^{\mathrm{b}} \pm 0.009$ & $0.35^{\mathrm{b}} \pm 0.007$ \\
T4 & $0.386^{\mathrm{a}} \pm 0.006$ & $0.416^{\mathrm{a}} \pm 0.003$ & $0.446^{\mathrm{a}} \pm 0.012$ & $0.41^{\mathrm{a}} \pm 0.007$ \\
$\begin{array}{c}\text { Level of } \\
\text { significance }\end{array}$ & $* *$ & $* *$ & $* *$ & $* *$ \\
\hline
\end{tabular}

$\mathrm{T}_{1}$ : Control; $\mathrm{T}_{2}$ : $50 \mathrm{mg} \mathrm{L-carnitine/kg}$ of diet; $\mathrm{T}_{3}: 100 \mathrm{mg} \mathrm{L-carnitine/kg}$ of diet;

$\mathrm{T}_{4}: 150 \mathrm{mg} \mathrm{L}$-carnitine/ $\mathrm{kg}$ of diet.

Means having different superscripts in the same column are significantly different.

** $(P<0.01)$. 
Table 3 Effect of dietary L-carnitine on mass activity of spermatozoa (\%) (mean \pm SE) of drakes

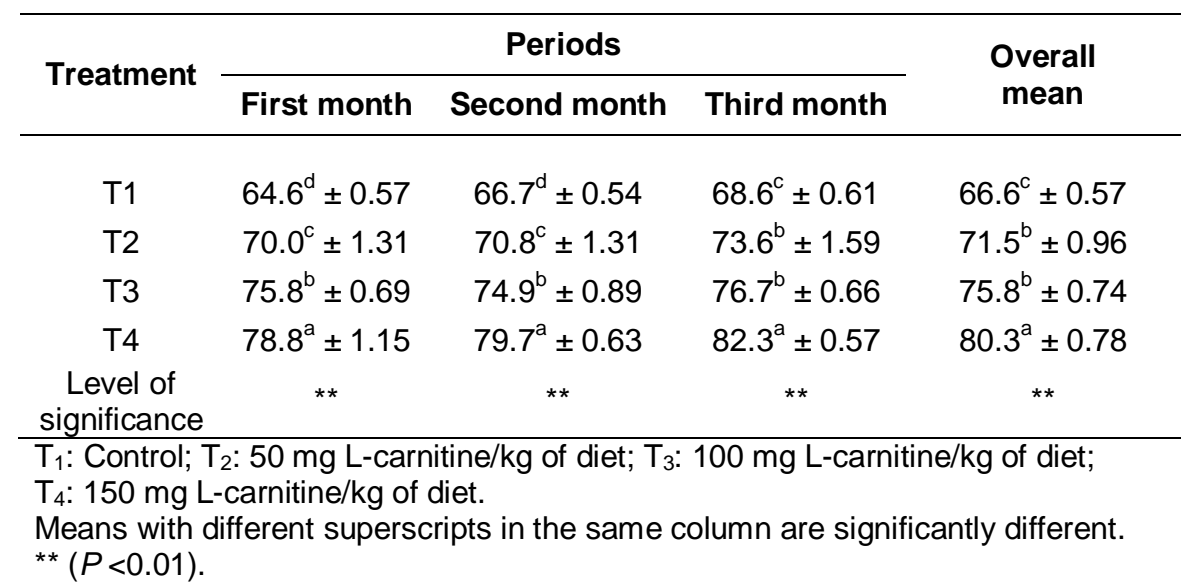

Table 4 Effect of dietary L-carnitine on individual motility of spermatozoa (\%) (mean \pm SE) of drakes

\begin{tabular}{|c|c|c|c|c|}
\hline \multirow{2}{*}{ Treatment } & \multicolumn{3}{|c|}{ Periods } & \multirow{2}{*}{$\begin{array}{l}\text { Overall } \\
\text { mean }\end{array}$} \\
\hline & First month & Second month & Third month & \\
\hline $\mathrm{T} 1$ & $73.8^{c} \pm 0.94$ & $74.3^{c} \pm 0.60$ & $74.8^{\mathrm{c}} \pm 0.32$ & $74.3^{c} \pm 0.62$ \\
\hline $\mathrm{T} 2$ & $76.8^{b c} \pm 1.14$ & $77.6^{b} \pm 0.63$ & $78.4^{b c} \pm 1.09$ & $77.9^{\mathrm{bc}} \pm 0.95$ \\
\hline T3 & $78.0^{b} \pm 0.75$ & $79.4^{b} \pm 0.39$ & $80.3^{b} \pm 1.11$ & $79.2^{b} \pm 0.75$ \\
\hline $\mathrm{T} 4$ & $83.9^{a} \pm 1.07$ & $86.2^{a} \pm 0.90$ & $89.6^{a} \pm 2.26$ & $86.6^{a} \pm 1.41$ \\
\hline $\begin{array}{c}\text { Level of } \\
\text { significance }\end{array}$ & ** & $\star \star$ & $\star \star$ & ** \\
\hline
\end{tabular}

Table 5 Effect of dietary L-carnitine on spermatocrit (\%) (mean \pm SE) of drakes

\begin{tabular}{|c|c|c|c|c|}
\hline \multirow{2}{*}{ Treatment } & \multicolumn{3}{|c|}{ Periods } & \multirow{2}{*}{$\begin{array}{l}\text { Overall } \\
\text { mean }\end{array}$} \\
\hline & First month & Second month & Third month & \\
\hline T1 & $15.8^{C} \pm 0.36$ & $16.2^{c} \pm 0.40$ & $16.8^{C} \pm 0.14$ & $16.3^{c} \pm 0.30$ \\
\hline $\mathrm{T} 2$ & $17.7^{b c} \pm 0.57$ & $17.7^{\mathrm{bc}} \pm 0.54$ & $18.4^{b} \pm 0.36$ & $17.9^{b} \pm 0.49$ \\
\hline T3 & $18.1^{\mathrm{b}} \pm 0.43$ & $18.5^{\mathrm{b}} \pm 0.54$ & $19.1^{b} \pm 0.30$ & $18.5^{b} \pm 0.42$ \\
\hline $\mathrm{T} 4$ & $20.2^{\mathrm{a}} \pm 0.96$ & $22.3^{c} \pm 0.61$ & $23.0^{\mathrm{a}} \pm 0.34$ & $21.8^{a} \pm 0.63$ \\
\hline $\begin{array}{c}\text { Level of } \\
\text { significance }\end{array}$ & ** & $\star \star$ & $\star *$ & $\star \star$ \\
\hline
\end{tabular}

The lowest sperm concentration was observed in the control group. There were significant differences $(P<0.01)$ in means of spermatozoa concentration between the drakes in $\mathrm{T}_{1}$ and other treatment groups, while there were no differences $(P>0.05)$ among $T_{2}, T_{3}$ and $T_{4}$ in the third month of experiment. As shown in Table 7 , the percentages of dead spermatozoa decreased $(P<0.01)$ owing to dietary L-carnitine supplementation. No differences were found between $\mathrm{T}_{2}$ and T3 $\left(20.36\right.$ and $18.9 \times 10^{9} \mathrm{cell} / \mathrm{sL}$, respectively). 
The effects of L-carnitine supplementation on the percentage of abnormal spermatozoa are shown in Table 8. There was a lower $(P<0.01)$ percentage of abnormal spermatozoa in $\mathrm{T}_{2}, \mathrm{~T}_{3}$ and $\mathrm{T}_{4}(16.8 \%, 15.7 \%$ and $13.6 \%$, respectively) compared with the control (18.5\%). No differences $(P>0.05)$ were observed between $\mathrm{T}_{2}$ and $\mathrm{T}_{3}$ in the second and third month. Results contained in Table 9 show that consumption of L-carnitine reduced $(P<0.01)$ the percentage of acrosomal abnormalities. The highest average of percentage of acrosomes abnormalities (12.3\%) was found in the first month of the control group, while the lowest (7.5\%) was in the second month of $\mathrm{T}_{4}$.

Table 6 Effect of dietary L-carnitine on spermatozoa concentration $\left(\times 10^{9} / \mathrm{mL}\right)(\mathrm{mean} \pm \mathrm{SE})$ of drakes

\begin{tabular}{|c|c|c|c|c|}
\hline \multirow{2}{*}{ Treatment } & \multicolumn{3}{|c|}{ Periods } & \multirow{2}{*}{$\begin{array}{l}\text { Overall } \\
\text { mean }\end{array}$} \\
\hline & First month & Second month & Third month & \\
\hline $\begin{array}{l}\text { T1 } \\
\text { T2 } \\
\text { T3 } \\
\text { T4 }\end{array}$ & $\begin{array}{c}2.30^{\mathrm{c}} \pm 0.15 \\
3.10^{\mathrm{b}} \pm 0.37 \\
3.60^{\mathrm{a}} \pm 0.20 \\
4.30^{\mathrm{a}} \pm 1.00\end{array}$ & $\begin{array}{l}2.46^{\mathrm{d}} \pm 0.47 \\
3.63^{\mathrm{c}} \pm 1.67 \\
4.10^{\mathrm{b}} \pm 1.00 \\
4.67^{\mathrm{a}} \pm 1.67\end{array}$ & $\begin{array}{l}2.33^{\mathrm{c}} \pm 0.67 \\
3.67^{\mathrm{b}} \pm 1.67 \\
3.90^{\mathrm{b}} \pm 1.00 \\
4.77^{\mathrm{a}} \pm 0.33\end{array}$ & $\begin{array}{l}2.36^{\mathrm{c}} \pm 0.22 \\
3.46^{\mathrm{b}} \pm 0.55 \\
3.86^{\mathrm{b}} \pm 0.33 \\
4.58^{\mathrm{a}} \pm 0.11\end{array}$ \\
\hline $\begin{array}{c}\text { Level of } \\
\text { significance }\end{array}$ & $\star *$ & ** & $\star \star$ & ** \\
\hline
\end{tabular}

Table 7 Effect of dietary L-carnitine on Percentages of dead spermatozoa (\%) (mean \pm SE) of drakes

\begin{tabular}{|c|c|c|c|c|}
\hline \multirow{2}{*}{ Treatment } & \multicolumn{3}{|c|}{ Periods } & \multirow{2}{*}{$\begin{array}{l}\text { Overall } \\
\text { mean }\end{array}$} \\
\hline & First month & Second month & Third month & \\
\hline $\mathrm{T} 1$ & $23.5^{a} \pm 0.58$ & $23.0^{\mathrm{a}} \pm 1.00$ & $22.1^{\mathrm{a}} \pm 0.92$ & $22.8^{a} \pm 0.83$ \\
\hline $\mathrm{T} 2$ & $20.5^{b} \pm 0.98$ & $21.5^{\mathrm{ab}} \pm 0.82$ & $19.1^{b} \pm 0.64$ & $20.4^{b} \pm 0.81$ \\
\hline T3 & $19.2^{b} \pm 0.72$ & $19.8^{\mathrm{b}} \pm 1.11$ & $17.7^{\mathrm{b}} \pm 0.01$ & $18.9^{b} \pm 0.61$ \\
\hline T4 & $16.3^{c} \pm 0.33$ & $16.7^{c} \pm 0.61$ & $15.3^{c} \pm 0.38$ & $16.1^{\mathrm{c}} \pm 0.44$ \\
\hline $\begin{array}{l}\text { Level of } \\
\text { significance }\end{array}$ & ** & $\star \star$ & $\star \star$ & $\star *$ \\
\hline
\end{tabular}

Table 8 Effect of dietary L-carnitine on abnormal spermatozoa (\%) (mean \pm SE) of drakes

\begin{tabular}{|c|c|c|c|c|}
\hline \multirow{2}{*}{ Treatment } & \multicolumn{3}{|c|}{ Periods } & \multirow{2}{*}{$\begin{array}{l}\text { Overall } \\
\text { mean }\end{array}$} \\
\hline & First month & Second month & Third month & \\
\hline $\mathrm{T} 1$ & $19.2^{a} \pm 0.69$ & $18.1^{a} \pm 0.76$ & $18.2^{a} \pm 0.76$ & $18.5^{\mathrm{a}} \pm 0.73$ \\
\hline $\mathrm{T} 2$ & $17.6^{b} \pm 0.58$ & $16.3^{b} \pm 0.15$ & $16.4^{b} \pm 0.57$ & $16.8^{\mathrm{b}} \pm 0.43$ \\
\hline T3 & $15.9^{c} \pm 0.26$ & $15.7^{\mathrm{b}} \pm 0.31$ & $15.6^{b} \pm 0.43$ & $15.7^{b} \pm 0.33$ \\
\hline $\mathrm{T} 4$ & $14.3^{d} \pm 0.15$ & $13.3^{c} \pm 0.53$ & $13.3^{c} \pm 0.46$ & $13.6^{c} \pm 0.38$ \\
\hline $\begin{array}{c}\text { Level of } \\
\text { significance }\end{array}$ & $\star \star$ & $\star \star$ & $\star *$ & $\star \star$ \\
\hline \multicolumn{5}{|c|}{$\begin{array}{l}\mathrm{T}_{1} \text { : Control; } \mathrm{T}_{2}: 50 \mathrm{mg} \mathrm{L} \text {-carnitine/kg of diet; } \mathrm{T}_{3}: 100 \mathrm{mg} \mathrm{L} \text {-carnitine/kg of diet; } \\
\mathrm{T}_{4}: 150 \mathrm{mg} \mathrm{L} \text {-carnitine/kg of diet. } \\
\text { Means with different superscripts in the same column are significantly differer } \\
\star * *(P<0.01) \text {. }\end{array}$} \\
\hline
\end{tabular}


Table 9 Effect of dietary L-carnitine on acrosomal abnormalities (\%) (mean \pm SE) of drakes

\begin{tabular}{|c|c|c|c|c|}
\hline \multirow{2}{*}{ Treatment } & \multicolumn{3}{|c|}{ Periods } & \multirow{2}{*}{$\begin{array}{l}\text { Overall } \\
\text { mean }\end{array}$} \\
\hline & First month & Second month & Third month & \\
\hline $\mathrm{T} 1$ & $12.3^{\mathrm{a}} \pm 0.72$ & $11.9^{\mathrm{a}} \pm 0.34$ & $10.8^{a} \pm 0.23$ & $11.7^{\mathrm{a}} \pm 0.43$ \\
\hline $\mathrm{T} 2$ & $10.7^{\mathrm{ab}} \pm 0.84$ & $10.0^{b} \pm 0.22$ & $09.5^{b} \pm 0.42$ & $10.1^{\mathrm{b}} \pm 0.49$ \\
\hline T3 & $9.3^{b c} \pm 0.66$ & $8.7^{c} \pm 0.11$ & $8.8^{b c} \pm 0.43$ & $8.8^{b c} \pm 0.40$ \\
\hline $\mathrm{T} 4$ & $7.8^{c} \pm 0.13$ & $7.5^{d} \pm 0.06$ & $7.7^{c} \pm 0.21$ & $7.7^{\mathrm{c}} \pm 0.13$ \\
\hline $\begin{array}{c}\text { Level of } \\
\text { significance }\end{array}$ & ** & ** & ** & ** \\
\hline \multicolumn{5}{|c|}{$\begin{array}{l}\mathrm{T}_{1}: \text { Control; } \mathrm{T}_{2}: 50 \mathrm{mg} \mathrm{L} \text {-carnitine } / \mathrm{kg} \text { of diet; } \mathrm{T}_{3}: 100 \mathrm{mg} \text { L-carnitine } / \mathrm{kg} \text { of diet; } \\
\mathrm{T}_{4}: 150 \mathrm{mg} \mathrm{L} \text {-carnitine } / \mathrm{kg} \text { of diet. } \\
\text { Means with different superscripts in the same column are significantly different. } \\
\star \star \star \\
\star(P<0.01) .\end{array}$} \\
\hline
\end{tabular}

The significant improvement in semen quality traits is evident from an increase in means of the ejaculate volume (Table 2), mass and individual motility of spermatozoa (Tables 3 and 4), spermatocrit (Table 5) and spermatozoa concentration (Table 6), and decreasing means of percentages of dead and abnormal spermatozoa and acrosomal abnormalities (Tables 7, 8 and 9, respectively). This may be because of the role of carnitine in the oxidation of long-chain fatty acids, which improves spermatogenesis within the seminiferous tubules of the testis (Neuman et al., 2002). Spermatogenesis is the sequence of events that transform spermatogonia into mature spermatozoa and improves the semen qualities. Fat is used to build the membrane of the sperm, and has an important role in sperm metabolism and fertilizing ability. The composition of lipids in the sperm membrane is regarded as the main factor determining the effectiveness of sperms and sperm parameters (sperm count, motility and viability) (Kelso et al., 1997). In addition, carnitine has a pivotal role in the movement of sperm. During the passage of sperm from the head to the tail of the epididymis, the carnitine concentration increased significantly (Enomoto et al., 2002; Kobayashi et al., 2007). Therefore, it is believed that the acquisition of sperm movement is synchronized with the increasing concentration of carnitine in those sperms (Jeulin \& Lawrence, 1996). The carnitine itself is an energy substrate to support the movement of sperm (Al-Daraji, 2007b).

The reason for the improvement in semen quality of males that were treated with carnitine is owing to the effectiveness of carnitine as a powerful antioxidant and it prevents the creation of free radicals in the semen (Agarwal \& Said, 2004). This can be explained by the presence of high quantities of long-chain polyunsaturated fatty acids (PUFA) in the membrane of avian spermatozoa. The peroxides reduce the lifespan of the sperm in vivo during fertilization or during laboratory conservation in vitro (Agarwal et al., 2005). Peroxides also lead to fundamental changes in the composition of sperm, especially the acrosome area, and cause a sharp decline in the motility of sperm. Free radicals reduce sperm motility and vitality, and prevent the reaction of the acrosome with the membrane (Aitken \& Clarkson, 1987; Aitken et al., 1993). Carnitine prevents the formation of free radicals, which form peroxides that cause oxidation or destroy free radicals (Sarica et al., 2007). The action of carnitine in these cases is similar to those of vitamins $\mathrm{A}$ and $\mathrm{E}$ (Neuman et al., 2002), which work on the mid piece of sperm, thus providing protection to the sperm membrane and acrosome (Aitken et al., 1993). In addition, the role of carnitine takes place in the metabolism of long-chain fatty acids, where it reduces their accumulation in the semen or reproductive tracts (Agarwal \& Said, 2004), and consequently reduces the opportunities for oxidation and formation of free radicals (Vicari \& Calogero, 2001). The carnitine, which is effective in eliminating free radicals or reactive oxygen species, is more likely to be formed by the free iron in the body and works on the degradation of cell membranes. Carnitine can bind with free iron because it has a chelating property, thus decreases the chances of the formation of free radicals and active oxygen species (Kalaiselvi \& Panneerselvam, 1998).

The significant improvement in semen quality of the male ducks as a result of L-carnitine supplementation may be attributed to the roles of follicle-stimulating hormone (FSH) and luteinising hormone (LH). This was evident by an increase in the concentrations of FSH, $\mathrm{LH}$, and testosterone in the blood serum of these males (unpublished data). FSH is directly responsible for stimulating the process of spermatogenesis, an increase in testis size, Sertoli cell differentiation, and seminiferous tubules size (O'Shaughnessy et al., 2010). On the other hand, LH plays a basic role in the differentiation and maturation of Leydig cells and testosterone production in the interstitial tissue of the testis. Testosterone has an important role in spermatogenesis and the improvement of semen quality and quantity (Weinbauer \& 
Nieschlag, 1991; Squires, 2003). A high concentration of this hormone enhances growth and maintenance of testes (Rommerts, 1990; Jacyno et al., 2007). Positive effects of carnitine on spermatogenesis have been reported in previous studies, where sperm concentration, ejaculated volume and number of live sperms increased (Palmero et al., 1990; Vitali et al., 1995; Matalliotakis \& Koumantakis, 2000; Neuman et al., 2002; Zhai et al., 2008b).

\section{Conclusion}

In conclusion, feeding diets containing different levels of L-carnitine resulted in a significant improvement of semen quality and quantity traits in this study on Iraqi drakes. Therefore, L-carnitine could be used as an efficient feed additive to improve the reproductive performance of male ducks.

\section{References}

Agarwal, A. \& Said, T.M., 2004. Carnitine and male infertility. Reprod. Biomed. Online 8 (4), 376-384.

Agarwal, A., Prabakaran, A.S.A. \& Said, T.M., 2005. Prevention of oxidative stress mini-review injury to sperm. J. Andrology 26 (6), 654-660.

Aitken, R.J. \& Clarkson, J. S., 1987. Cellular basis of defective sperm function and its association with the genesis of reactive oxygen species by human spermatozoa. J. Reprod. Fertil. 81, 459-469.

Aitken, R.J., Harkiss, D. \& Buckingham, D.W., 1993. Analysis of lipid peroxidation mechanisms in human spermatozoa. Mol. Reprod. Dev. 35, 302-315.

Al-Daraji, H.J., 2007a. Artificial insemination in domestic birds. Ministry of Higher Education and Scientific Research, University of Baghdad, College of Agriculture, Baghdad, Iraq.

Al-Daraji, H.J., 2007b. Avian Reproductive Physiology. Ministry of Higher Education and Scientific Research, University of Baghdad, College of Agriculture, Baghdad, Iraq.

Al-Daraji, H.J., Al-Tikriti, B.T.O., Hassan, K.H. \& Al-Rawi, A.A., 2002. New techniques for determination of avian spermatozoa abnormalities. Res. J. Bio. Technol. 4 (1), 47-64.

Al-Daraji, H.J., Al-Mashadani, H.A., Al-Hayani, W.K. \& Merza, H.A., 2012. The first trial for semen collection and artificial insemination in duck and geese birds in Iraq by using new techniques. Patent issued from C.O.S.Q.C. No. 3367 on 5 / 1 / 2012.

Al-Hayani, W.K., 2012. The uses of different levels of L-carnitine for improve productive performance of Guinea Fowl. PhD. Dissertation, College of Agriculture, University of Baghdad, Baghdad, Iraq.

Arslan, C., Citil, M. \& Saatci, M., 2003. Effect of L-carnitine administration on growth performance, carcass traits, blood serum parameters and abdominal fatty acid composition of ducks. Arch. Anim. Nutr. 57 (5), 381-388.

Benvenga, S., Amato, A., Calvani, M. \& Trimarchi, F., 2004. Effects of carnitine on thyroid hormone action. Ann. N.Y. Acad Sci. 1033, 158-67.

Duncan, D.B., 1955. Multiple range and multiple F-test. Biometrics 11, 1-42.

Elgazzar, U.B., Ghanema, I.I.A. \& Kalaba, Z.M., 2012. Effect of dietary L-carnitine supplementation on the concentration of circulating serum metabolites in growing New Zealand rabbits. Aust. J. Bas. Appl. Sci. 6 (2), 80-84.

Enomoto, A., Wempe, M.F., Tsuchida, H., Shin, H.J., Cha, S.H., Anzai, N., Goto, A., Sakamoto, A., Niwa, T. \& Kanai, Y., 2002. Molecular identification of a novel carnitine transporter specific to human testis. J. Biolog. Chem. 277, 36262-36271.

Golzar Adabi, S., Moghaddam, G., Taghizadeh, A., Nematollahi, A. \& Farahvash, T., 2006. Effect of L-carnitine and vegetable fat on broiler breeder fertility, hatchability, egg yolk and serum cholesterol and triglyceride. Int. J. Poult. Sci. 5, 970-974.

Griffin, H.D., Windsor, D. \& Zammit, V.A., 1990. Regulation of carnitine palmitoyltransferase 1 in chick liver. Biochem. Soc. Trans. 18, 981-982.

Jacyno, E., Kolodzinj, A., Kamyczek, M., Kawecka, M., Dziadek, K. \& Pietruszka, A., 2007. Effect of L-carnitine supplementation on boar semen quality. Acta. Vet. 76, 595-600.

Jeulin, C. \& Lawrence, M.L., 1996. Role of L-carnitine and acetyl L-carnitine in post-gonadal maturation of mammalian spermatozoa. Human Reproduction Update 2 (2), 87-102.

Kalaiselvi, T. \& Panneerselvam, C., 1998. Effect of L-carnitine on the status of lipid peroxidation and antioxidants in aging rats. J. Nutr. Biochem. 9, 575-581.

Karadeniz, A., Simsex, N. \& Cakir, S., 2008. Haematological effects of dietary L-carnitine supplementation in broiler chickens. Revue Méd. Vét. 159 (8-9), 437-444.

Kelso, K.A., Redpath, A., Noble, C. \& Speake, B.K., 1997. Lipid and antioxidant changes in spermatozoa and seminal plasma throughout the reproductive period of bulls. J. Reprod. Fertil. 109, 1-6.

Kleber, H.P., 1997. Bacterial carnitine metabolism. FEMS Microbiol. Lett. 147 (1), 1-9. 
Kobayashi, D., Tamail, I., Sai, Y.I., Yoshida, K., Wakayama, T., Kido, Y., Nezu, J., Iseki, S. \& Tsuji, A., 2007. Transport of carnitine and acetylcarnitine by carnitine/organic cation transporter (OCTN) 2 and OCTN3 into epididymal spermatozoa. Reproduction 134, 651-658.

Leibetseder, J., 1995. Studies on the effects of L-carnitine in poultry. Arch. Anim. Nutr. 48, 97-108.

Matalliotakis, I. \& Koumantakis, E., 2000. L-carnitine levels in the seminal plasma of fertile and infertile men: correlation with sperm quality. Int. J. Fert. Womens Med. 45, 236-240.

Neuman, S.L., Lint, T.L. \& Hester, P.Y., 2002. The effect of dietary carnitine on semen traits of White Leghorn roosters. Poult. Sci. 81, 495-503.

Ng, C.M., Blackman, M.R., Wang, C. \& Swerdloff, R.S., 2004. The role of carnitine in the male reproductive system. In: Carnitine: The Science behind a Conditionally Essential Nutrient. Vol. 1033. Eds: Alesci, S., Manoli, S.I., Costello, R., Coates, P., Gold, P.W., Chrousos, G.P. \& Blackman, M.R., Ann. N.Y. Acad. Sci., New York, NY. pp. 177-188.

NRC, 1994. Nutrient Requirements of Poultry, 9th rev. ed. National Research Council, National Academy Press, Washington, D.C., USA.

O'Shaughnessy, P.J., Monteiro, A., Verhoeven, G., De Gendt, K. \& Abel, M.H., 2010. Effect of FSH on testicular morphology and spermatogenesis in gonadotrophin-deficient hypogonadal mice lacking androgen receptors. Reproduction 139, 177-184.

Palmero, S., Leone, M., Prati, M., Costa, M., Messeni, M., Fugassa, E. \& Cecco, L.D., 1990. The effect of $\mathrm{L}$-acetylcarnitine on some reproductive functions in the oligoasthenospermic rat. Horm. Metab. Res. 22, 622-626.

Rommerts, F.F.G., 1990. Testosterone: An overview of biosynthesis, transport, metabolism, and action. In: Testosterone, Action, Deficiency and Substitution (1st ed.). Eds: Nieschlag, E. \& Behre, H.M., Springer - Verlag, Berlin, Heidelberg. pp. 3.

Sarica, M., Corduk, M., Suicmez, F., Cedden, M., Yildirim, K., \& Kilinc, L., 2007. The effects of dietary L-carnitine supplementation on semen traits, reproductive parameters, and testicular histology of Japanese quail breeders. J. Appl. Poult. Res. 16, 178-186.

SAS, 2004. Statistical Anylysis System user's guide. Release Version 7.00. SAS Institute, Cary, North Carolina, USA.

Squires, R., 2003. Use of carnitine therapy in selected cases of male factor infertility: A double-blind crossover trial. Fertil. Steril. 79, 292-300.

Vicari, E. \& Calogero, A.E., 2001. Effects of treatment with carnitine in infertile patients with prostatevesiculo-epididymitis. Hum. Reprod. 16 (11), 2338-2348.

Vitali, G., Parente, R. \& Melottic, C., 1995. Carnitine supplementation in human idiopathic asthenospermia : clinical result. Drug Exp. Clin. Res. 21, 157-159.

Weinbauer, G.F. \& Nieschlag, E., 1991. Peptide and steroid regulation of spermatogenesis in primates. Ann. NY Acad. Sci. 367, 107-121.

Zhai, W., Neuman, S.L., Latour, M.A. \& Hester, P.Y., 2007. The effect of dietary L-carnitine on semen traits of white leghorns. Poult. Sci. 86, 2228-2235.

Zhai, W., Neuman, S.L., Latour, M.A. \& Hester, P. Y., 2008a. The effect of in ovo injection of L-carnitine on hatchability of White Leghorns. Poult. Sci. 87, 569-572.

Zhai. W., Neuman, S.L., Latour, M.A. \& Hester, P.Y., 2008b. The effect of male and female supplementation of L-carnitine on reproductive traits of white Leghorns. Poult. Sci. 87, 1171-1181. 